\title{
Effects of sensory stimuli on the incidence of fetal resorption in a murine model of spontaneous abortion: the presence of an alien male and postimplantation embryo survival
}

\author{
M. G. Baines ${ }^{1}$, E. K. Haddad ${ }^{1}$, D. K. Pomerantz ${ }^{2}$ and A. J. Duclos ${ }^{1}$ \\ ${ }^{1}$ Department of Microbiology and Immunology, McGill University, Montréal, Québec, Canada; and \\ ${ }^{2}$ Department of Physiology, University of Western Ontario, London, Ontario, Canada
}

\begin{abstract}
Pregnancy outcome may be altered by both genetic and environmental factors. The mating of $\mathrm{CBA} / \mathrm{J}$ female mice with $\mathrm{DBA} / 2$ males normally results in pregnancies characterized by a relatively high incidence of early embryo loss compared with most other syngeneic or allogeneic matings. This study addressed the role of normal laboratory stress in the induction of early embryo loss. The previously studied 'Bruce effect' describes the total loss of preimplantation embryos (pregnancy block) that is apparently caused by the stress induced by the presence of an alien male and mediated by neuroimmunological effects on prolactin activity. To determine whether this effect could be responsible for the high incidence of postimplantation embryo losses in the $\mathrm{CBA} / \mathrm{J} \times \mathrm{DBA} / 2$ model, the original $\mathrm{DBA} / 2$ male was replaced on day 6 of gestation by another DBA 2 male, a CBA/J, a $\mathrm{C} 57 \mathrm{Bl} / 6$ or a $\mathrm{BALB} / \mathrm{c}$ male. The relatively high incidence of embryo loss was not affected by removing the original $\mathrm{DBA} / 2$ male or introducing another $\mathrm{DBA} / 2$ or a $\mathrm{CBA} / \mathrm{J}$ male, indicating that stress induced by an alien male did not increase the postimplantation losses in this model. Furthermore, the introduction of a DBA 2 male to a $C B A / J$ female that had been mated with a $B A L B / c$ male did not elicit early embryo loss. However, the replacement of the original $\mathrm{DBA} / 2$ male by a $\mathrm{BALB} / \mathrm{c}$ male dramatically reduced the incidence of early embryo loss in pregnant $\mathrm{CBA} / \mathrm{J}$ female mice. The introduction of a $\mathrm{C} 57 \mathrm{Bl} / 6$ male also reduced embryo loss but to a lesser extent. Furthermore, this effect was shown to be independent of the testes and was induced by factors present in the bedding from cages in which $\mathrm{BALB} / \mathrm{c}$ male mice had been housed. The presence of the BALB/C male in the cage with the pregnant $\mathrm{CBA} / \mathrm{J}$ female resulted in a significant reduction in the infiltration of uterine implantation sites by maternal macrophages, coincident with a reduction in early embryo losses. These studies therefore show that the maternal cell-mediated immune response in the uterus to the fetal graft is altered, apparently by pheromonal messages derived from the resident male. The introduction of an alien $B A L B / c$ male to a pregnant $\mathrm{CBA} / \mathrm{J}$ female after implantation of $\mathrm{CBA} / \mathrm{J} \times \mathrm{DBA} / 2$ embryos had occurred, while unable to alter the fetal genotype, apparently altered the maternal uterine cellular response and had a profound effect on pregnancy outcome.
\end{abstract}

\section{Introduction}

Many of the causes and mechanisms responsible for spontaneous abortion in the early postimplantation period have not been clearly established. Causes of reproductive failure include anatomical abnormalities of the reproductive system, genetic anomalies of the gametes, endocrine abnormalities, microbial infections or immunological problems (Clark and Chaouat, 1989). By using pathogen-free inbred animals to study reproductive biology, genetic anomalies related to the reproductive or endocrine systems can be eliminated, allowing the investigator to focus upon the immunological factors. Since the

Revised manuscript received 19 April 1994. original report made by Clark et al. (1980) on the relatively high incidence of early embryo resorption of $\mathrm{CBA} / \mathrm{J}$ females mated with DBA $/ 2$ males, this and other models of embryo loss have been characterized in great detail (Chaouat et al., 1988; Gendron and Baines, 1989; Clark et al., 1990).

Although it appears that the immune system of the mother plays a very important role in mediating early embryo survival during the early postimplantation period, it is also clear that the maternal response to the conceptus is, in part, paternally induced (Slapsys and Clark, 1983; Bulmer and Johnson, 1985; Nakayama et al., 1985; Mitchell et al., 1990; Nichikawa et al., 1991). The mechanisms causing spontaneous early embryo loss appear to involve natural killer (NK) cells in the $\mathrm{CBA} / \mathrm{J} \times$ $\mathrm{DBA} / 2$ system. Gendron and Baines (1988) found that NK-like 
cells infiltrated $20-30 \%$ of the embryos between day 6 and day 8 of gestation, and that the proportion of infiltrated embryos was correlated with the observed resorption frequency that was macroscopically observable on day 12 of gestation. The effector molecules include the macrophage cytokine tumour necrosis factor $\alpha$ (TNF- $\alpha$ ) and the activation of macrophages during pregnancy provides a possible mechanism to explain early embryo loss (Gendron et al., 1990b). During successful pregnancy, these maternal defence mechanisms appear to be suppressed because of the local production of nonspecific immunoregulatory factors, including prostaglandins and transforming growth factors (TGF) and possibly interleukin 10 (Lala, 1989; Graham and Lala, 1991; Wegmann et al., 1993). Our results, and those of others have shown that the local activation or suppression of maternal cell-mediated defence mechanisms in selected embryos is specific to certain strains of males, implying a genetic basis for successful pregnancy enhancement (Clark et al., 1986, 1987; Bobe and Kiger, 1989; Gendron et al., 1990a).

Although immunological factors can affect embryo survival directly, nonimmunological factors have also been shown to influence the reproductive function of females. For example, the Whitten effect, which describes the synchronization of oestrus in grouped females accompanied by increased fecundity, was reported by Whitten (1966). Conversely, stress, whether due to mechanical restraint (Wiebold et al, 1986), noise (Clark et al., 1993) or social hierarchy (Huck et al., 1988), has been shown to have profound negative effects on pregnancy outcome.

It has been known for some time that the presence of other male or female mice, even without physical contact, can alter the reproductive functions of the female mouse (Bruce, 1959). Bruce and co-workers showed that exposing mated female mice to an alien male within $48 \mathrm{~h}$ of coitus blocked pregnancy owing to failure of implantation of the blastocyst in nearly $80 \%$ of the females (Bruce, 1959, 1960, 1961; Bruce and Parrott, 1960). The effectiveness of the alien male in terminating pregnancy diminished after implantation had occurred, and was lost by day 6 of pregnancy (Bruce, 1961). Although the 'Bruce effect' was at first thought to be a phenomenon confined to male effects on pregnancy, later studies have shown that the introduction of major histocompatibility complex (MHC) allogeneic females to the mated female could also induce a pregnancy block (Yamazaki et al., 1983a, b). Additional studies clearly demonstrated that the alien male elicited the implantation blocking effect via androgen-dependent pheromones, which were present in male urine and which acted via a maternal neuroendocrine pathway involving decreased prolactin and progesterone secretion (Bruce and Parrott, 1960; Dominic, 1965, 1966a, b). It is important to point out that the phenomenon reported by Bruce and co-workers was strictly a preimplantation effect, as the ability of the alien male to block pregnancy diminished after implantation, and was totally lost after day 6 of gestation (Bruce, 1961). Moreover, the 'Bruce effect' caused total litter loss, as a return to oestrus was the result of Bruce's experiments.

The purpose of the present study was to determine whether the postimplantation male-related embryo losses observed in the $\mathrm{CBA} / \mathrm{J} \times \mathrm{DBA} / 2$ model are due to factors related to sensory stimuli. The results show that the presence of an alien male can either positively or negatively influence the outcome of pregnancy after implantation has occurred.

\section{Material and Methods}

\section{Animals}

Virgin CBA/J female mice $\left(\mathrm{H}-2^{\mathrm{k}}\right)$ were mated with $\mathrm{DBA} / 2$ $\left(\mathrm{H}-2^{\mathrm{d}}\right)$ or BALB/c $\left(\mathrm{H}-2^{\mathrm{d}}\right)$ males (Jackson, Bar Harbor, ME or Charles River, St-Constant, Canada) to provide initial pregnancies. To avoid crowding effects and to allow the female and male to condition their cage environment, each mating pair was placed in a separate cage and the female was examined daily for the presence of a copulatory plug. The day of detection of the copulatory plug was designated as day 0 of gestation. After the detection of the copulatory plug, the male remained in the mating cage with the pregnant female until implantation had occurred (day 6 of gestation). The pregnant CBA/J female was then submitted to one of the following experiments: replacing the original $\mathrm{DBA} / 2$ male with another $\mathrm{DBA} / 2$ male, a $\mathrm{BALB} / \mathrm{c}$ male, a CBA/J male or a $\mathrm{C} 57 \mathrm{Bl} / 6$ male $(\mathrm{H} 2-\mathrm{b})$. For $\mathrm{CBA} / \mathrm{J}$ female $\times \mathrm{BALB} / \mathrm{c}$ male pregnancies a $\mathrm{DBA} / 2$ male was used to replace the original $\mathrm{BALB} / \mathrm{c}$ male. To determine whether male-derived pheromonal factors were responsible for the observed effects, pregnant females were transferred to a cage containing the soiled bedding from a BALB/c male. To determine whether male endocrine factors were involved, a BALB/c male that had been castrated 2-5 weeks earlier under ether anaesthesia was placed in the cage with the pregnant female.

\section{Determination of the incidence of spontaneous abortion}

Pregnant mice were killed on day 12 of gestation by cervical dislocation and the uterus and embryos were examined. Upon examining the uterus, the resorbing embryos appeared small and black (haemorrhagic, ischaemic) compared with the larger, red, healthy fetoplacental implants. The resorption frequency was calculated as follows:

$100 \times$ resorbing embryos/(resorbing + viable embryos).

\section{Immunohistochemistry}

Pregnant mice were killed on day 8 of gestation and fetoplacental units were removed, frozen in Tissue-Tek OCT compound (Miles Diagnostic, IN) on dry ice and stored at $-20^{\circ} \mathrm{C}$ until used for cryosectioning. Frozen sections, $8 \mu \mathrm{m}$ thick, were air-dried, fixed in $100 \%$ acetone for $10 \mathrm{~min}$ at room temperature, air-dried for $1 \mathrm{~h}$ and stained for the localization of cells positive for Mac-1 (CDIIb) using an indirect peroxidaseanti-peroxidase technique, as described by Gendron and Baines (1988). The CDIIb marker is associated with the $\mathrm{C} 3$ bi receptor and is expressed by granulocytes, macrophages and NK cells. Briefly, Mac-1 (American Type Culture Collection, Rockville, MD) monoclonal primary antibodies were allowed to react with the sections for $90 \mathrm{~min}$; a rabbit anti-rat immunoglobulin polyclonal antiserum was then added (Serotec, Toronto) followed by an excess of goat anti-rabbit immunoglobulin affinity-purified polyclonal antiserum (Jackson Immunoresearch Laboratories, Avondale, PA). The localization of the primary antibody was visualized by incubating the section in a rabbit peroxidase-anti-peroxidase complex followed by incubation with diaminobenzidine substrate for $15 \mathrm{~min}$ (Sigma Chemical 
Table 1. Effects of normal animal handling stress on embryo loss in mice

$\mathrm{CBA} / \mathrm{J}$ females mated with $\mathrm{DBA} / 2$ males

Treatment of females
Number
CBA/J females mated with BALB/c males

$\begin{array}{lrrrrr}\text { Male in cage with female } & 7 & 8.7 \pm 0.8 & 22.1 \pm 2.1 & 6 & 10.0 \pm 0.5 \\ \text { Male removed from cage } & 12 & 9.3 \pm 0.3 & 23.1 \pm 1.8 & \text { ND } & 4.7 \pm 1.9 \\ \text { Females in a group cage } & 12 & 7.8 \pm 0.7 & 23.8 \pm 4.4 & 12 & 9.4 \pm 0.5\end{array}$

$\mathrm{CBA} / \mathrm{J}$ female mice were mated with the indicated strain of male, which was either left in the cage with the female or was removed, leaving the female alone in the cage. Alternatively, the females were removed from the mating cage and placed in a group cage with other females mated on the same day.

No significant differences from expected results were observed.

ND: not determined.

Co., St Louis, MO). Endogenous peroxidase was quenched by incubating the sections in a $3 \%(\mathrm{v} / \mathrm{v})$ hydrogen peroxide (Sigma Chemical Co.) solution in $100 \%$ methanol, after addition of the primary antibody. The slides were lightly counterstained with Carazzi's haematoxylin for $15 \mathrm{~s}$. Negative controls were not reacted with the primary anti-macrophage antibody (Mac- -1 ). Mac-1-positive cells in a tissue section through the centre of each embryonic capsule (including the entire embryo, trophoblast and deciduum) were counted at a magnification of $\times 400$.

\section{Statistical analyses}

The data were analysed using the Tukey-Kramer multiple range test, and groups were compared by the Student's $t$ test. Results are shown as arithmetic means \pm SEM. Upper and lower $95 \%$ confidence limits were computed as the mean $\pm 1.96 \times \mathrm{SD}$ (1.96 $\pm \mathrm{SD})$.

\section{Results}

Effects of alien males on embryo resorption in the $C B A / J \times D B A / 2$ model

The normal experimental procedure for the mating of $\mathrm{CBA} / \mathrm{J}$ females involved some degree of stress, associated with the inspection of the females for vaginal plugs, the removal of the mated females from their cages and their placement in a new cage with the other females mated on the same day. To determine whether this stress affected early embryo loss rates, $\mathrm{CBA} / \mathrm{J}$ females were mated with either $\mathrm{DBA} / 2$ or $\mathrm{BALB} / \mathrm{c}$ males and, except for inspection for the vaginal plug, were left untouched until the females were examined for early embryo resorption on day 12 (Table 1 ). No differences from the expected results were observed for either group, as $23 \%$ of the embryos from matings with $\mathrm{DBA} / 2$ resorbed compared with only $4 \%$ for matings with $B A L B / C$ males. The removal of the mating male from the mating cage while leaving the $\mathrm{CBA} / \mathrm{J}$ female in the original cage, or regrouping the pregnant females in a new group cage, did not have a significant effect on the resorption frequency observed by macroscopic examination on day 12 (Table 1). Therefore, whether the original male remained with the mated female or was removed from the original cage did not alter the higher incidence of embryo loss induced by matings with a DBA $/ 2$ male. This indicated that handling stress per se was not responsible for the observed embryo losses.

Since mating with $B A L B / c$ or $C B A / J$ males was associated with a lower incidence of embryo loss, and since Bruce (1960) had shown that alien males could induce pregnancy block in mice, the effects of introducing different males to the pregnant females were examined (Table 2). The possible induction of preimplantation embryo losses due to the 'Bruce effect' was avoided by introducing different males on day 6 of gestation. (Implantation usually occurs between day 4 and day 5 after mating.) The continued presence of the original $\mathrm{DBA} / 2$ male in the cage with the pregnant $\mathrm{CBA} / \mathrm{J}$ female had no effect on embryo loss (Table 1 ). The removal of the original male and the introduction of a different $\mathrm{DBA} / 2$ male or a $\mathrm{CBA} / \mathrm{J}$ male also had no significant effect on pregnancy outcome. However, the introduction of a BALB/c male on day 6 of gestation significantly reduced the incidence of embryo resorption observed on day $12(P<0.001$; Table 2). The introduction of a $C 57 \mathrm{Bl} / 6$ male also reduced the incidence of embryo loss to a lesser extent $(P<0.05)$. All the groups of females showed no significant differences in the number of implantation sites on day 12 , indicating that the manipulation of the mice and their cages had not precipitated the Bruce effect. Thus, the presence of a $\mathrm{BALB} / \mathrm{C}$ or $\mathrm{C} 57 \mathrm{Bl} / 6$ male in the cage with the pregnant $\mathrm{CBA} / \mathrm{J}$ female (from a mating with a DBA/2 male) was sufficient to enhance early postimplantation embryo survival.

To determine whether the presence of a DBA $/ 2$ male could similarly jeopardize the outcome of matings by other males, $\mathrm{CBA} / \mathrm{J}$ female mice were mated with $\mathrm{BALB} / \mathrm{c}$ male mice (Table 3). The introduction of a DBA $/ 2$ male to the pregnant female after a $\mathrm{CBA} / \mathrm{J}$ female $\times \mathrm{BALB} / \mathrm{c}$ male mating did not significantly affect the resorption frequency observed on day 12 . The $\mathrm{BALB} / \mathrm{c}$ male appeared to be the most effective alien male among those tested, while another allogeneic male (C57B//6) partially reduced early embryo loss.

\section{Pheromonal factors involved in embryo rescue by $B A L B / c$ males}

Previous experiments have shown that preimplantation pregnancy block can be induced by pheromonal components derived from the urine of the alien male. Pregnant CBA/J females that had been mated with $D B A / 2$ males were placed in cages that had previously been soiled by BALB/c males for 3 
Table 2. Fetal resorption in $\mathrm{CBA} / \mathrm{J}$ female mice when the mating $\mathrm{DBA} / 2$ male was replaced by an alien male

\begin{tabular}{lccccc}
\hline \multirow{2}{*}{ New male } & Number of & Implantations & \multicolumn{2}{c}{ Embryo status } & \multirow{2}{*}{$\begin{array}{c}\text { Percentage } \\
\text { resorption }\end{array}$} \\
& $\mathrm{CBA} / \mathrm{J}$ female & per uterus & Viable & Resorbing & \\
None & 12 & $9.3 \pm 0.3$ & 85 & 26 & $23.4 \pm 1.8$ \\
$\mathrm{DBA} / 2$ & 7 & $8.7 \pm 0.8$ & 48 & 13 & $21.3 \pm 2.1$ \\
$\mathrm{CBA} / \mathrm{J}$ & 8 & $8.0 \pm 0.3$ & 51 & 13 & $20.3 \pm 2.1$ \\
$\mathrm{C} 57 \mathrm{BI} / 6$ & 6 & $10.0 \pm 0.4$ & 52 & 8 & $13.3 \pm 3.3^{*}$ \\
$\mathrm{BALB} / \mathrm{c}$ & 10 & $9.6 \pm 0.4$ & 92 & 4 & $4.2 \pm 2.3^{* * *}$ \\
\hline
\end{tabular}

Number of viable and resorbing embryos on day 12 are presented for each of the groups in which a new male replaced the original mating male on day 6 of pregnancy.

Differences were analysed using Student's $t$ test for significance on resorption frequencies calculated for each group of females:

*significantly different from control group (None) at $P<0.05 ;{ }^{* * *}$ significantly different from control group (None) at $P<0.001$.

Table 3. Fetal resorption in $\mathrm{CBA} / \mathrm{J}$ female mice when the mating $\mathrm{BALB} / \mathrm{c}$ male was replaced by an alien male

\begin{tabular}{lccccc}
\hline New male & $\begin{array}{c}\text { Number of } \\
\text { CBA/J females }\end{array}$ & $\begin{array}{c}\text { Implantations } \\
\text { per uterus }\end{array}$ & Viable & Resorbing & $\begin{array}{c}\text { Percentage } \\
\text { resorption }\end{array}$ \\
\hline None & 12 & $6.6 \pm 0.6$ & 80 & 5 & $5.6 \pm 2.0$ \\
DBA/2 & 7 & $10.4 \pm 0.5$ & 66 & 7 & $9.3 \pm 1.6$ \\
BALB/c & 6 & $10.0 \pm 0.5$ & 57 & 3 & $4.7 \pm 1.9$ \\
\hline
\end{tabular}

Number of viable and resorbing embryos on day 12 are presented for each of the groups of mice in which a new male replaced the original mating male on day 6 of pregnancy.

Differences were analysed using the Tukey-Kramer test for significance on resorption frequencies calculated for each group of females: no significant difference was observed for any group.

Table 4. Factors contributing to the rescuing effect of BALB/C males on embryo loss in mice

\begin{tabular}{lccccc}
\hline New male & $\begin{array}{c}\text { Number of } \\
\text { CBA/J females }\end{array}$ & $\begin{array}{c}\text { Implantations } \\
\text { per uterus }\end{array}$ & Viable & resorbing & $\begin{array}{c}\text { Percentage } \\
\text { resorption }\end{array}$ \\
\hline None & 7 & $8.7 \pm 0.8$ & 48 & 13 & $21.3 \pm 2.1$ \\
BALB/c & 10 & $9.6 \pm 0.4$ & 92 & 4 & $4.2 \pm 2.3^{*}$ \\
Castrate BALB/c & 9 & $8.1 \pm 0.4$ & 67 & 6 & $8.6 \pm 2.1^{*}$ \\
BALB/c bedding & 9 & $8.4 \pm 0.4$ & 69 & 7 & $9.2 \pm 2.6^{*}$ \\
\hline
\end{tabular}

Number of viable and resorbing embryos on day 12 are presented for each group of females to which a new male was introduced on day 6 of pregnancy.

Differences were analysed using the Tukey-Kramer test for significance on resorption frequencies calculated for each group of females: *significantly different from control group (None) $P<0.01$.

days (Table 4). Early embryo losses for CBA/J females in contact with only the cage bedding soiled by $\mathrm{BALB} / \mathrm{c}$ males were also dramatically reduced $(P<0.01)$. In fact, this treatment was as effective as the actual presence of the male itself $(P<0.01$; Tukey-Kramer), which implied that the rescuing factor was secreted or excreted by the males. The ability of the $\mathrm{BALB} / \mathrm{c}$ male to rescue the fetuses of the $\mathrm{CBA} / \mathrm{J} \times \mathrm{DBA} / 2$ mating could therefore have been exerted wholly, or in part, by pheromones present in the soiled litter, and were possibly derived from the urine or faeces of the $\mathrm{BALB} / \mathrm{c}$ male.

To determine whether there was a possible gonadal involvement in the rescuing ability of $B A L B / c$ males, adult $B A L B / C$ males were castrated 2-5 weeks before being used to replace $\mathrm{DBA} / 2$ males in cages with mated $\mathrm{CBA} / \mathrm{J}$ female mice. 


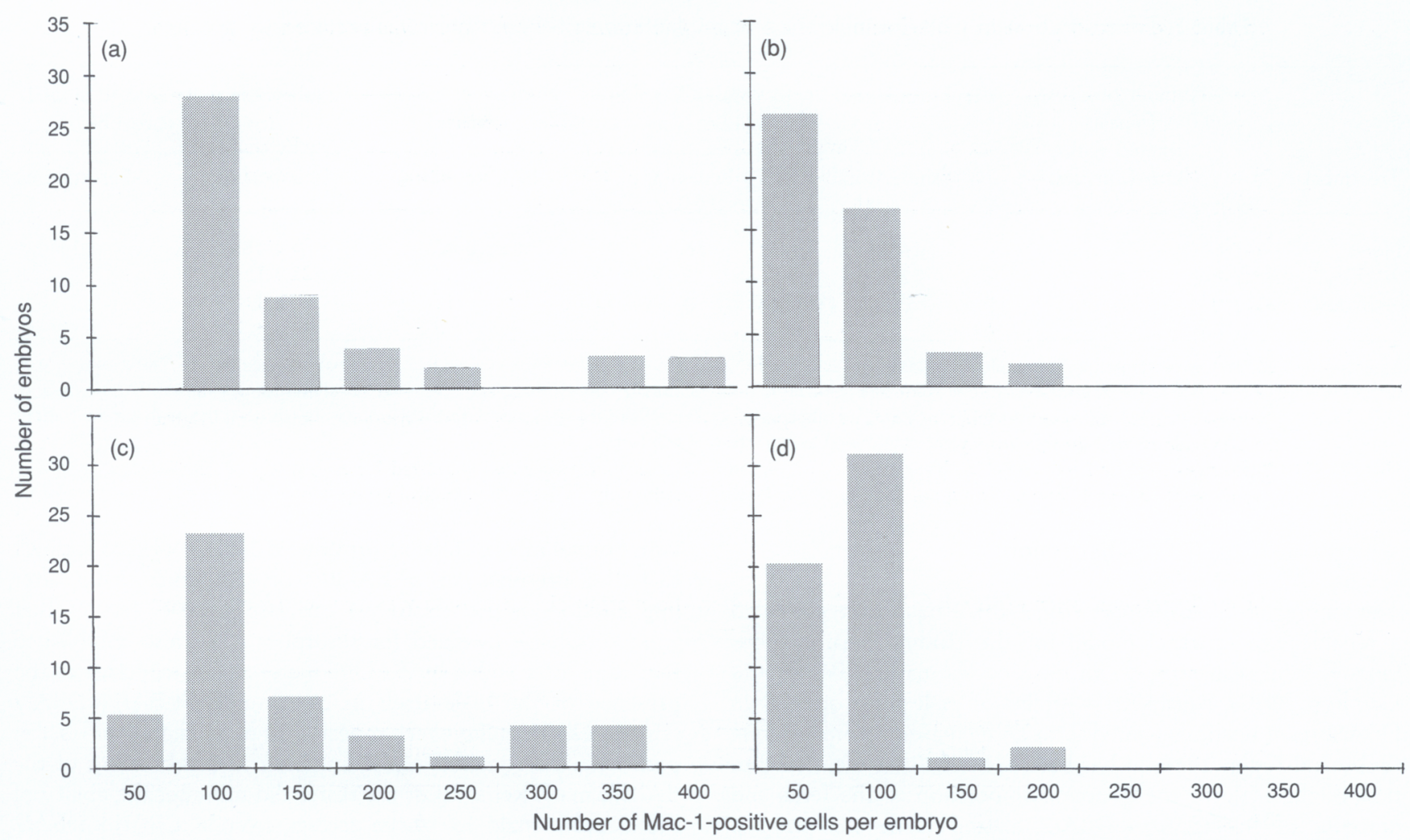

Fig. 1. Effect of an alien male on the distribution of Mac-I-positive cells in the uteri of pregnant CBA/J female mice. CBA/J female mice were mated with $\mathrm{DBA} / 2$ males and used to determine the frequency distribution of Mac-1-positive cells during pregnancy. Experimental groups included (a) $\mathrm{CBA} / \mathrm{J} \times \mathrm{DBA} / 2$, (b) $\mathrm{CBA} / \mathrm{J} \times \mathrm{BALB} / \mathrm{c}$, (c) $\mathrm{CBA} / \mathrm{J} \times \mathrm{DBA} / 2$, with the mating male replaced by a new $\mathrm{DBA} / 2$ male, and (d) $\mathrm{CBA} / \mathrm{J} \times \mathrm{DBA} / 2$, with the mating male replaced by a new $\mathrm{BALB} / \mathrm{c}$ male on day 6 of pregnancy. Pregnant mice were killed on day 8 of gestation and the implantation sites were analysed for Mac-1-positive cells by immunohistochemistry. The number of macrophages per embryo site are indicated on the abscissa in increments of 50 (e.g. 50 represents the range from 50 to 99).

Gonadectomized $\mathrm{BALB} / \mathrm{c}$ males could also rescue $\mathrm{CBA} / \mathrm{J} \times$ DBA/2 embryos $(P<0.01$; Tukey-Kramer) (Table 4). These data indicate that the rescuing effect of the $\mathrm{BALB} / \mathrm{c}$ male is apparently independent of the testes.

\section{Pheromonal effects on cell-mediated response in the uterus}

As the BALB/c-derived pheromonal effect appeared to alter the survival of the $\mathrm{CBA} / \mathrm{J} \times \mathrm{DBA} / 2$ embryos implanted in the uterus of the $\mathrm{CBA} / \mathrm{J}$ female, the maternal effector cell response must have been altered. To determine whether the prevention of resorption observed on day 12 of gestation by the introduction of $\mathrm{BALB} / \mathrm{c}$ males or their bedding on day 6 altered the maternal response at the fetoplacental interface, the number of Mac-1-positive cells present at the fetoplacental interface in frozen sections of uteri on day 8 were analysed. The Mac-1positive cells observed in the implantation sites were predominantly mononuclear cells, of which $15-20 \%$ also expressed class II MHC antigens and $75-80 \%$ expressed the $\mathrm{F} 4 / 80$ antigen. The Mac-1 monoclonal antibody produced the most consistent results in preliminary evaluations and was chosen as the marker for this study. The upper $95 \%$ confidence limit for a normal infiltrate of Mac-1-positive cells was calculated to be 181 cells per central section of each embryonic unit. The frequency distribution of Mac-1-positive cells was similar for
$\mathrm{CBA} / \mathrm{J}$ females that had either been directly mated with a $\mathrm{DBA} / 2$ male or that had been exposed to a new DBA $/ 2$ male on day 6 (Fig. 1). These two groups showed similar implantation and resorption frequencies, and when they were examined under a microscope on day 8 they showed relatively larger numbers of decidual macrophages. However, if $\mathrm{CBA} / \mathrm{J}$ females were mated with $\mathrm{DBA} / 2$ males and then introduced to a $B A L B / c$ male on day 6 , the profile was similar to a $\mathrm{CBA} / \mathrm{J} \times \mathrm{BALB} / \mathrm{c}$ mating, in that the total number of macrophages was lower than in the $\mathrm{CBA} / \mathrm{J} \times \mathrm{DBA} / 2$ mating and few of the implantation sites showed significant infiltration by Mac-1-positive cells. The introduction of the BALB/c male to a $\mathrm{CBA} / \mathrm{J}$ female previously mated with a $\mathrm{DBA} / 2$ male therefore altered both the incidence of embryo loss and the nature of the decidual macrophage infiltrate.

Moreover, when the number of significantly infiltrated embryonic units was analysed in each of the four groups (Table 5), $\mathrm{CBA} / \mathrm{J}$ females mated with $\mathrm{DBA} / 2$ males introduced to a $\mathrm{BALB} / \mathrm{c}$ male on day 6 had a similar proportion of significantly infiltrated embryonic units to that of $\mathrm{CBA} / \mathrm{J}$ females mated with $\mathrm{BALB} / \mathrm{c}$ males. While the direct involvement of maternal cellular effectors in embryo loss was clear, the data provided no insight into the neuroimmunoregulatory pathways that were responsible for the observed effect of sensory stimuli on early embryo survival. 
Table 5. Effect of an alien male on infiltration of implantation sites by maternal macrophages in mice

\begin{tabular}{|c|c|c|c|c|c|c|}
\hline \multirow[b]{2}{*}{ Treatment } & \multirow{2}{*}{$\begin{array}{c}\text { Number of CBA } / \mathrm{J} \\
\text { females } \\
\text { mated with } \\
\mathrm{DBA} / 2 \text { males }\end{array}$} & \multicolumn{2}{|c|}{$\begin{array}{l}\text { Embryonic units with } 95 \% \text { UCL value } \\
\text { for } C B A / J \times B A L B / c\end{array}$} & \multirow{2}{*}{$\begin{array}{c}\text { Number of } \mathrm{CBA} / \mathrm{J} \\
\text { females } \\
\text { mated with } \\
\text { BALB/c males }\end{array}$} & \multicolumn{2}{|c|}{$\begin{array}{l}\text { Embryonic units with } 95 \% \text { UCL } \\
\text { for } \mathrm{CBA} / \mathrm{J} \times \mathrm{BALB} / \mathrm{c}\end{array}$} \\
\hline & & Number/total & Percentage & & Number/total & Percentage \\
\hline None & 6 & $14 / 49$ & 28.57 & 6 & $4 / 48$ & 8.33 \\
\hline$+\mathrm{DBA} / 2$ male & 6 & $12 / 47$ & 25.53 & & ND & \\
\hline + BALB/c male & 6 & $0 / 55$ & 0 & & ND & \\
\hline
\end{tabular}

Macrophage infiltrates were stained with immunoperoxidase and counted for each embryo implantation site on day 8 of gestation (see Fig. 1). The expected $95 \%$ upper confidence limit (UCL) (i.e. the mean $\pm 1.96 \times$ so for Mac-1-positive cells infiltrating nonresorbing embryos) was calculated using $\mathrm{CBA} / \mathrm{J} \times \mathrm{BALB} / \mathrm{C}$ matings ( $95 \%$ UCL $=181 \mathrm{Mac}-1$-positive cells per implantation site). The numbers of implantation sites of the experimental groups that showed macrophage infiltrations consisting of more than $181 \mathrm{Mac}-1$-positive cells were determined as a fraction of the total.

ND: not determined.

\section{Discussion}

The mating of $C B A / J$ female with $D B A / 2$ male mice provided a reliable experimental model for the study of early spontaneous fetal resorption in an intraspecies mating (Baines and Gendron, 1993). Because few strains of male mice other than $\mathrm{DBA} / 2$ have been associated with an increased resorption rate (Bobe and Kiger, 1989), it has been assumed that the contribution of the male to the genetic composition of the fetus and placenta of the $\mathrm{CBA} / \mathrm{J} \times \mathrm{DBA} / 2$ mating made the embryo particularly susceptible to recognition by maternal defence mechanisms, and was therefore more easily rejected. An alternative explanation was that the $\mathrm{CBA} / \mathrm{J} \times \mathrm{DBA} / 2$ conceptus could not produce appropriate cytokines or respond to the intrauterine cytokines essential for optimal placental and embryo development, and that the embryo failed to survive. Apparently, it had not been considered that exogenous factors, such as the housing conditions or handling stress, might contribute to fetal resorption in this particular mating combination. The studies reported here reveal that the presence of the male mouse could influence the outcome of pregnancy by altering the intrauterine cellular microenvironment after implantation of the blastocyst.

Because the studies of the Bruce effect were concerned chiefly with the blockade of implantation, data had not previously been collected concerning the possible effects of alien males on the incidence of fetal resorption when they were introduced to the female after implantation (Bruce, 1959). Our initial study addressed the question of postimplantation embryo loss induced by alien males. We showed that the number of implantation sites and the incidence of fetal resorption in $\mathrm{CBA} / \mathrm{J}$ females mated with $\mathrm{DBA} / 2$ males was not different if the $\mathrm{CBA} / \mathrm{J}$ female remained with the original mating $\mathrm{DBA} / 2$ male or if the original mating male was substituted on day 6 of gestation with another DBA/2, CBA/J or $\mathrm{C} 57 \mathrm{Bl} / 6$ male. Unexpectedly, the substitution of the $\mathrm{DBA} / 2$ male with a $\mathrm{BALB} / \mathrm{c}$ male on day 6 was associated with a significant improvement in fetal survival to levels associated with those matings not prone to resorption. It has been shown that both mating CBA/J females with BALB/C males (Clark et al., 1980) or immunizing females with spleen cells from $B A L B / c$ males but not females before mating with DBA $/ 2$ males (Chaouat et al., 1983; Kiger et al., 1985; Clark et al., 1986, 1987) are associated with normal rates of fetal resorption (5-10\%). Our data suggest that the presence of a $\mathrm{BALB} / \mathrm{c}$ or allogeneic male after implantation of the blastocyst can also 'rescue' fetuses that were otherwise destined for resorption. We also established that cage litter soiled by $B A L B / c$ males was as effective as the presence of the male itself in rescuing the $\mathrm{CBA} / \mathrm{J} \times \mathrm{DBA} / 2$ fetuses. The rescuing effect appeared to be mediated, at least in part, by a pheromonal signal lingering in the bedding of the $\mathrm{BALB} / \mathrm{c}$ male. Removal of the testes did not alter the ability of the $B A L B / c$ male to rescue fetuses from a $C B A / J \times D B A / 2$ mating. The putative pheromone is not therefore dependent on the testis for its production.

The phenomena we have observed have important differences from the effect described by Bruce and co-workers, in that they described pregnancy failure while we have described pregnancy enhancement. In our study, the influence of the male on pregnancy outcome was exerted after implantation rather than before. The effect was exerted by both $B A L B / c$ and $\mathrm{C} 57 \mathrm{Bl} / 6$ males, but the $\mathrm{BALB} / \mathrm{c}$ male had the most significant rescuing effect. Furthermore, because both $\mathrm{DBA} / 2$ and $\mathrm{BALB} / \mathrm{c}$ mice expressed the same $\mathrm{H}-2^{\mathrm{d}}$ haplotype of the MHC complex, we concluded that the gene(s) encoding the rescuing effect was located outside the MHC complex. This interpretation was supported by demonstrating that third-party $\mathrm{C} 57 \mathrm{Bl} / 6$ males could also induce this effect. We found that the rescuing effect was still elicited by BALB/C males that had been castrated 2-5 weeks before testing, unlike the early pregnancy block observed by Bruce (1960). Either the effect of the BALB/c male was not independent of the testes, or a more prolonged period of gonadectomy was required to allow the residual androgenmediated effect to dissipate. Studies to address this possibility are currently underway.

Earlier work from our laboratory provided information about the potential immune mechanisms involved in fetal loss in the $\mathrm{CBA} / \mathrm{J} \times \mathrm{DBA} / 2$ model. We showed that a significant infiltration of NK cells into approximately $25 \%$ of implantation sites occurred between day 6 and day 8 of gestation (Gendron and Baines, 1988). We proposed that this infiltration was associated with concurrent infiltration and local activation of maternal leucocytes (A. J. Duclos, D. K. Pomerantz and M. G. Baines, unpublished data), and that the production of TNF- $\alpha$ (Gendron et al., 1990b) ultimately contributed to the destruction of the developing placenta in the affected implantation 
site(s), leading to fetal death and resorption. We therefore examined the effect of introducing a BALB/c male on day 6 of gestation of a $C B A / J \times D B A / 2$ pregnancy on the Mac-1positive population at the decidual-placental interface on day 8. While Mac-1 is expressed by several cell populations (for example, B cells, polymorphonuclear leucocytes and macrophages), previous studies have shown that few B cells and PMNs are present in early implantation sites. Our finding that introducing a $\mathrm{BALB} / \mathrm{C}$ male resulted in a significant reduction in the infiltration of uterine implantation sites by maternal macrophages showed that the rescuing effect of the BALB/c male may have been mediated by altering the stimulation or regulation of the maternal innate immune system. Furthermore, this observation constituted another argument in favour of the link between macrophage infiltration and spontaneous embryo loss observable in later gestation. The ultimate role of these macrophages in the developing embryo is still controversial, since macrophages may be involved in either the suppression of a potentially dangerous maternal immune response via prostaglandin release (Stenson and Preker, 1980; Hunt $e$ t al., 1985) or in the rejection of the fetus by the maternal immune system via the local release of cytotoxic factors (Yelavarthi et al., 1991).

In conclusion, a unique role for the resident male in determining postimplantation embryo survival has been observed. In contrast to the ability of an alien male to induce total preimplantation pregnancy block, certain males may be able to enhance postimplantation embryo survival. In both cases, the effect of the alien male on reproductive outcome is induced by male-derived pheromones, and is presumably mediated by neuroendocrine signals that alter the nature of the maternal cell-mediated immune response to the conceptus. The nature of the difference between the males capable of inducing low versus high rates of embryo loss remains to be determined. However, these data indicate that, in some cases, male-derived pheromonal stimuli may play a role in eliciting or preventing early pregnancy loss.

The authors thank K. Billingsley and E. Antecka. This project was supported in part by a grant from the Medical Research Council of Canada.

\section{References}

Baines MG and Gendron RL (1993) Natural and experimental animal models of reproductive failure. In Immunology of Pregnancy pp 173-203 Ed. G Chaouat. CRC Press, Boca Raton.

Bobe $\mathbf{P}$ and Kiger $\mathbf{N}$ (1989) Immunogenetic studies of spontaneous abortion in mice. III. Non-H-2 antigens and gestation Journal of Immunogenetics 16 233-231

Bruce HM (1959) An exteroceptive block to pregnancy in the mouse Nature 184105

Bruce HM (1960) Block to pregnancy in the mouse caused by proximity of strange males Journal of Reproduction and Fertility 1 96-103

Bruce HM (1961) Time relations in the pregnancy-block induced in mice by strange males Journal of Reproduction and Fertility 2 138-142

Bruce HM and Parrott DVM (1960) Role of olfactory sense in pregnancy block induced by strange males Science 131 1526-1527

Bulmer JN and Johnson PM (1985) Immunohistological characterization of the decidual leucocytic infiltrate related to endometrial gland epithelium in early human pregnancy Immunology 55 35-44

Chaouat G, Kiger N and Wegmann TG (1983) Vaccination against spontaneous abortion in mice Journal of Reproductive Immunology 5 389-392
Chaouat G, Clark DA and Wegmann TG (1988) Genetic aspects of the CBA/J $\times$ $\mathrm{DBA} / 2$ and $\mathrm{B} 10 \times \mathrm{B} 10 . \mathrm{A}$ models of murine pregnancy failure and its prevention by lymphocyte immunization. In Early Pregnancy Failure: Mechanisms and Treatments p 102 Eds RW Beard and F Sharp. Peacock Press, Ashton-under-Lyne.

Clark DA and Chaouat G (1989) What do we know about spontaneous abortion mechanisms? American Journal of Reproductive Immunology 19 28-37

Clark DA, McDermott MR and Szewczuk MR (1980) Impairment of host-versusgraft reaction in pregnant mice. II. Selective suppression of cytotoxic T-cell generation correlates with soluble suppressor activity and with successful allogeneic pregnancy Cellular Immunology 52 106-118

Clark DA, Chaput A and Tutton D (1986) Active suppression of host-vs-graft reaction in pregnant mice: VII. Spontaneous abortion of allogeneic $\mathrm{CBA} / \mathrm{j} \times$ $\mathrm{DBA} / 2$ fetuses in the uterus of $\mathrm{CBA} / \mathrm{j}$ mice correlates with deficient non- $\mathrm{T}$ suppressor cell activity Journal of Immunology 136 1668-1675

Clark DA, Chaouat G, Guenet JL and Kiger N (1987) Local active suppression and successful vaccination against spontaneous abortion in $\mathrm{CBA} / \mathrm{J}$ mice Journal of Reproductive Immunology 10 79-85

Clark DA, Drake BL, Head JR, Stedronska-Clark J and Banwatt DK (1990) Decidua associated suppressor activity and viability of individual implantation sites of allopregnant C3H mice Journal of Reproductive Immunology 17 253-264

Clark DA, Banwatt DK and Chaouat G (1993) Stress-triggered abortion in mice prevented by alloimmunization American Journal of Reproductive Immunology 29 141-147

Dominic CJ (1965) The origin of the pheromones causing pregnancy block in mice Joumal of Reproduction and Fertility 10 469-475

Dominic CJ (1966a) Observations on the reproductive pheromones of mice. I. Source Journal of Reproduction and Fertility 11 407-414

Dominic CJ (1966b) Observations on the reproductive pheromones of mice. II. Neuroendocrine mechanisms involved in the olfactory block to pregnancy Journal of Reproduction and Fertility 11 415-421

Gendron RL and Baines MG (1988) Infiltrating decidual natural killer cells are asssociated with spontaneous abortion in mice Cellular Immunology 113 261-267

Gendron RL and Baines MG (1989) Morphometric analysis of the histology of spontaneous fetal resorption in a murine pregnancy Placenta 10 309-318

Gendron RL, Farookhi $\mathbf{R}$ and Baines MG (1990a) Resorption of CBA/J $\times D B A / 2$ mouse conceptuses in $\mathrm{CBA} / \mathrm{J}$ uteri correlates with failure of the feto-placental unit to suppress natural killer cell activity Joumal of Reproduction and Fertility $89277-284$

Gendron RL, Nestel FP, Lapp WS and Baines MG (1990b) Lipopolysaccharideinduced fetal resorption in mice is associated with the intrauterine production of tumour necrosis factor-alpha journal of Reproduction and Fertility 90 395-402

Graham CH and Lala PK (1991) Mechanism of control of trophoblast invasion in situ Journal of Cellular Physiology 148 228-234

Huck UW, Lisk RD, Miller KS and Bethel A (1988) Progesterone levels and socially-induced implantation failure and fetal resorption in golden hamsters (Mesocricetus auratus) Physiology and Behavior 44 321-326

Hunt JS, Marning LS, Mitchell MD, Selanders JR and Wood GW (1985) Localization and characterization of macrophages in murine uterus journal of Leukocyte Biology 38 255-261

Kiger N, Chaouat G, Kolb JP, Wegmann TG and Guenet JL (1985) Immunogenetic studies of spontaneous abortion in mice: preimmunization of females with allogeneic ceils Joumal of Immunology 134 2966-2970

Lala PK (1989) Similarities between immunoregulation in pregnancy and in malignancy: the role of $\mathrm{PGE}_{2}$ American Joumal of Reproductive Immunology 20 147-152

Mitchell MD, Edwin W and Romero RJ (1990) Prostaglandin biosynthesis by human decidual cells: effects of inflammatory mediators Prostaglandins Leukotrienes and Essential Fatty Acids 41 35-38

Nakayama E, Asano S, Kodo H and Miwa S (1985) Suppression of mixed lymphocyte reaction by cells of human first trimester pregnancy endometrium Journal of Reproductive Immunology 8 25-31

Nishikawa K, Saito S, Mori T, Hamada K, Ako H, Narita N, Ichijo M, Kurahasashi M and Sugamura K (1991) Accumulation of CD16-56 ${ }^{+}$NK cells with high affinity IL-2 receptor in human early pregnancy decidua International Immunology 3 743-750

Slapsys RM and Clark DA (1983) Active suppression of host-vs-graft reaction in pregnant mice. V. Kinetics, specificity and in vivo activity of non-T suppressor cells localized to the genital tract of mice during first pregnancy American Journal of Reproductive Immunology 3 65-71 
Stenson WF and Preker CW (1980) Opinion: prostaglandins, macrophages and immunity Journal of Immunology 125 1-3

Wegmann TG, Lin H, Guilbert L and Mossmann TR (1993) Bidirectional cytokine interactions in the maternal-fetal relationship: is successful pregnancy a Th2 phenomenon? Immunology Today 14 353-356

Whitten WK (1966) Pheromones and mammalian reproduction Advances in Reproductive Physiology 1 155-177

Wiebold JL, Stanfield PH, Becker WC and Hiller JK (1986) The effect of restraint stress in early pregnancy in mice Joumal of Reproduction and Fertility $\mathbf{7 8}$ 185-192
Yamazaki K, Beauchamp GK, Egorov IK, Bard J, Thomas L and Boyse EA (1983a) Sensory distinction between $\mathrm{H}-2 \mathrm{~b}$ and $\mathrm{H}-2 \mathrm{bmI}$ mutant mice Proceedings of the National Academy of Sciences, USA 80 5685-5688

Yamazaki K, Beauchamp GK, Wysocki CJ, Bard J, Thomas L and Boyse EA (1983b) Recognition of $\mathrm{H}-2$ types in relation to the blocking of pregnancy in mice Science 221 186-188

Yelavarthi KK, Chen HL, Yang Y, Fishback JL and Hunt JS (1991) TNF-alpha mRNA and protein in rat uterine and placental cells Journal of Immunology $1463840-3848$ 